\title{
THE GREENING OF ORGANISATIONAL IT: WHAT MAKES A DIFFERENCE?
}

\author{
Ben N Kuo \\ Geoffrey N Dick \\ University of New South Wales \\ Sydney 2052 Australia \\ Email: ben.kuo@student.unsw.edu.au \\ g.dick@unsw.edu.au
}

\begin{abstract}
The trend towards green information technology (IT) over the last few years is a result of an acknowledgement of both the environmental impact of IT and the role IT plays as a potential source of solutions to environmental concerns. As organisations are under increasing pressures to act sustainably, environmental considerations are taking greater importance for organisations and the organisations' information systems (IS) and IT. This paper introduces a model proposing competitive pressures, legitimation pressures, social responsibility pressures, organisational factors and technological constraints as factors which influence the extent of green IT in organisations. An online survey was developed and tested with IT practitioners. Regression analysis revealed that the extent of green IT in organisations is influenced by a combination of these factors. Foremost of the factors is the capability of the organisation to adapt. Other factors which account for differences in the extent of green IT in organisations include legitimation and social responsibility pressures. The regression indicated a good fit for the developed model, providing a basis for further research.
\end{abstract}

\section{INTRODUCTION}

Over the last few years, environmental sustainability has shifted from being solely the concern of scientists and environmentalists to being recognised as the most important and universal public issue today (Banerjee 2002; Bonini et al. 2008; United Nations Environment Programme 2008, p. iii). With intense political discussions and widespread coverage in the media (Enkvist et al. 2008; Friedman 2007), business executives expect environmental concerns to be the foremost issue which impacts on shareholder value in the future (Bonini et al. 2007). Environmental considerations now form important dimensions in corporate sustainability (PricewaterhouseCoopers \& SAM 2008), corporate social responsibility (St James Ethics Centre n.d.), corporate strategy (Enkvist \& 
Vanthournout 2008) and the 'triple bottom line' measure of organisational success, which is comprised of economic, social and ecological sustainability (Elkington 1998).

As a result, there has been increasing discussion on the role of information systems (IS) and information technology (IT), which has transformed the nature of many businesses, in improving the environmental performance of organisations that are under increasing pressure to implement sustainable practices.

With emerging technologies such as radio frequency identification (Organisation for Economic Cooperation and Development 2008) and mobile technology (Beurer-Zuellig \& Meckel 2008) increasingly being adopted, the information and communication technologies sector has grown from $5.8 \%$ of global GDP in 2002 to $7.3 \%$ in 2007 and is expected to comprise $8.7 \%$ of global GDP by 2020 (The Climate Group 2008). However, accompanying this growth are the increasing environmental impacts of the production, use and disposal of IT (Elliot \& Binney 2008). Rapid obsolescence of electronic products presents challenges in managing the electronic waste (e-waste) that causes environmental contamination (Herat \& Bahadir 2007). Furthermore, the increasing energy and resource demands of IT will primarily be met by fossil fuel based power plants, which contribute to the generation of greenhouse gases (GHG) that cause global warming and climate change (Katzer et al. 2007; The Climate Group 2008). However, in addition to the environmental impacts of IT in organisations, the role of IT in driving innovation, productivity and growth in organisations also makes it a potential source of solutions to improving organisational environmental performance (Ghose et al. 2008).

As an organisation's IS and IT are both a source of, and a solution to, organisational environmental degradation, there has seen the emergence of an area now generally termed 'green IT' where IS and IT are used to improve environmental performance. IT executives are expecting that "the 'Greenness' of IT suppliers would become 'much more important' over the next few years" (IDC 2008). Gartner $(2007,2008)$ has predicted green IT to be one of the top strategic technologies of 2008 and 2009 . Consequently, there is a need to identify and understand the factors which affect the environmental sustainability of an organisation's information systems as well as the use of information systems to address organisational environmental performance in general.

\section{BACKGROUND}

A number of potential factors that influence green IT were identified from organisational environmental strategy literature and then supplemented with preliminary academic green IT studies and the researchers' interviews with IT practitioners. From this review, three main factors were identified that have the potential to influence the extent to which the IT is used to improve environmental performance. These were: motivational factors, organisational factors and technological constraints.

\section{Motivational factors}

Determining and understanding the motives for organisations' environmental initiatives can assist in predicting environmentally based behaviours (Bansal \& Roth 2000) and hence can be a significant factor in the development of green IT in organisations. Bansal and Roth (2000), using analytic induction in a qualitative study of 53 firms, found three basic motivations that induce corporate environmental responsiveness: competitiveness, legitimation and social responsibility. 
Competitiveness focuses on profitability and encompasses initiatives that reduce costs, generate revenues or improve efficiencies. In contrast, the goal of legitimation is survival and hence, as a consequence, initiatives are based on satisfying government, local community and stakeholders, as well as compliance with norms and regulations in order to avoid penalties and lessen risks. The concern that organisations have for social good forms the social responsibility motivation where organisations act from "a sense of obligation, responsibility or philanthropy rather than out of selfinterest” (Bansal \& Roth 2000, p. 728).

Evidence of competitive and legitimation pressures on corporate environmental decision-making was also seen in Delmas and Toffel's (2008) study and a series of surveys conducted on UK firms as detailed in Ghobadian et al. (1998), James et al. (1999) and Faulkner, Carlisle and Viney (2005). It was found that organisations "adopt distinct sets of management practices that appease different external constituents" (Delmas \& Toffel 2008, p. 1027). These external groups were separated into market and nonmarket constituents. Market constituents such as competitors and customers would form the competitive pressures while nonmarket constituents such as environmental organisations, local community and regulators would form the legitimation pressures as they would exert legalregulatory influences and pressures from social expectations.

Functional departments within organisations may also exert pressures that affect the rest of the organisation as they are exposed to different sets of constituents. For example, sales and marketing departments focus on the market environment and hence this department would channel the pressures from market constituents. Legal affairs departments typically channel the pressures from nonmarket constituents to assure the organisational legitimacy and license to operate as they are "typically involved in regulatory compliance activities and addressing inquiries and complaints from local communities, activist groups, and the media" (Delmas \& Toffel 2008, p. 1032). Through direct channels such as control over decision making or indirect channels such as training, the influence of legal affairs departments is reflective of the receptiveness of the organisation to legitimation pressures.

In addition to external groups forming motivational pressures, certain internal goals also lead to organisations undertaking green initiatives. The pursuit of positive economic impact also forms part of the competitive pressures, with green initiatives potentially reducing costs or increasing revenues through green marketing or the sale of waste products (Ahmed \& Sharma 2006; Cordano 1993; Porter \& Van der Linde 1995). Other goals may include improving the perception and reputation of the organisation (Hart 1995; James et al. 1999; Russo \& Fouts 1997). Furthermore, internal ethical, social and ecological considerations, which would be defined within the social responsibility dimension, have been demonstrated to be very important in a German study, ranking them highly among the motivators for corporate sustainability activities (Hahn \& Scheermesser 2006).

Competitive, legitimation and social responsibility motives have also been suggested to influence green IT adoption as seen in Molla's (2008) Green IT Adoption Model where these motives corresponded to the economic, regulatory and ethical drivers of green IT. In Chen et al's (2008) application of institutional theory of how IS can be leveraged to achieve ecological sustainability, parallels can be drawn from the mimetic, normative and coercive pressures advocated in the conceptual paper to the definition of competitive and legitimation pressures in Bansal and Roth (2000). It can be seen mimetic pressures, "when organisational pressure to conform comes from other organizations and develops into an uncertainty-coping strategy" (Chen et al. 2008, p. 190), can form part of competitive pressures whilst normative pressures, "when cultural expectations press 
organizations to act in a legitimate way" (Chen et al. 2008, p. 190), and coercive pressures, "when organizations are driven to act alike because of governmental laws and regulations" (Chen et al. 2008, p. 190), can form part of legitimation pressures.

Recent empirical studies have also shown some preliminary evidence that these motives are applicable to green IT. Interviews by Sayeed and Gill (2008) identified that the main reasons given by interviewees for undertaking green IT initiatives were cost cutting and energy conservation. Molla, Pittayachawan and Corbitt (2009) also identified energy efficiency and cost cutting as the primary consideration of US organisations, whereas organisations in Australia and New Zealand seem to be primarily motivated by environmental considerations. In addition to these drivers, Elliot and Binney's (2008) case study also found that responsiveness to staff concerns and client requirements were also reasons for engaging in green IT. It was further expected that "government reporting, regulation and customer demand are potential drivers for the future" (Elliot \& Binney 2008 , p. 8). These initial studies show the presence of each of the competitive, legitimation and social responsibility dimensions of motivational factors influencing green IT within organisations.

\section{Organisational factors}

As green IT initiatives will have impacts on human resources and organisational capabilities (Sayeed \& Gill 2008), the extent of green IT is also likely to be influenced by organisational factors. An organisation's human resources and capabilities must be leveraged to manage environmental performance (Russo \& Fouts 1997). These factors, if not available in the appropriate quantity and at the necessary quality, may "constrain the company's ability to act" (Ghobadian et al. 1998, p. 18). These are typically more practical factors such as ongoing operational costs, the complexity of processes, the availability of resources and the capability of the organisation to adapt.

In addition to these factors, management support, especially senior management, has been identified as one of the most important internal organisational factors for environmental strategies. The importance of leadership and a senior management champion has been stressed in the literature (Ghobadian et al. 1998; James et al. 1999; Schein 2004), as key leaders shape the nature of organisations and determine the key issues the organisation addresses. They facilitate the requisition of resources, and environmental policy seems to follow a top-down progression.

\section{Technological constraints}

James et al. (1999) identified technology facilitation as a factor in the decision making process towards environmental strategies and in their study. This factor had varying importance playing a more significant role in determining environmental strategies in the manufacturing and petrochemical industries compared with the services, financial and utilities sectors. It has been suggested however, both by the researcher's own informal interviews with practitioners and Molla's (2008) conceptual Green IT Adoption Model that technological context may also influence the extent of green IT in organisations. Hence, given the exploratory nature of the study and the focus of the research in the IS and IT domain, it was decided this area should also be explored.

Some of the technological constraints that have been identified from the researcher's interviews include the limitations posed by software, hardware and infrastructure. Additionally, in Deloitte's (2008) publication on green IT, they viewed that the complexity of initiatives may also be one of the 
considerations in undertaking initiatives and technology may potentially be a significant factor in the extent of green IT across the organisation.

\section{Proposed model}

In summary the following model, which indicates the main factors proposed to influence the extent of green IT in organisations, was used to guide this study.

This study aims to answer the following question: what are the factors and to what extent do these factors influence the use of IT to improve environmental performance in organisations?

\section{METHODOLOGY}

A survey to test this model was administered to IT practitioners through an online questionnaire. This was distributed primarily through the use of mailing lists where potential respondents were invited to participate through a link included in an email. The mailing lists represented people known to have had experience working in at least one organisation in an IT related function.

The questionnaire was mostly developed by adapting existing literature in corporate environmental sustainability including studies by Delmas and Toffel (2008), Hahn and Scheermesser (2006), and a longitudinal series of studies from the UK (Faulkner, Carlisle \& Viney 2005; Ghobadian et al. 1998; James et al. 1999).

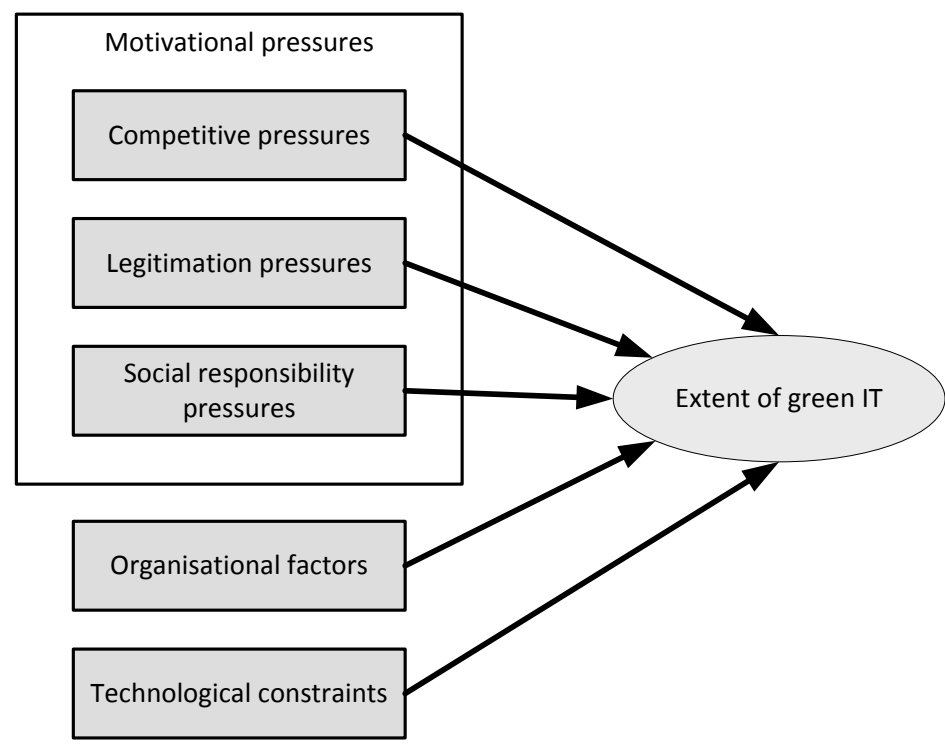

Figure 3 Research model showing the proposed factors which influence the extent of green IT in organisations

To measure the extent of green IT within an organisation, a self-reported six measure score was developed from the literature. Existing models to assess the maturity (Sayeed \& Gill 2008) and 
development (Elliot \& Binney 2008) of green IT within an organisation were unsuitable as they did not lend themselves for direct use in an online survey instrument. Instead, these models were utilised to formulate the measures used in this study. These measures were 5-point scales similar to semantic differentials where respondents are asked to rate their organisation along different continuums of opposing word pairs. These word pairs were developed from keywords identified from the literature which were often used to describe the extent of green IT in organisations. These words, which included 'ubiquitous', 'mature' and 'developed' (Elliot 2007; Sayeed \& Gill 2008), were matched with words that represented or closely represented their opposites to form the word pairs. These three word pairs were then further expanded to incorporate both the depth and breadth dimension as identified in the literature (Molla 2008; Molla, Pittayachawan \& Corbitt 2009).

Validity of the instrument was assessed in terms of content and construct validity. DeVellis (2003) recommends that in order to maximise the appropriateness when developing scales, an expert could review the items to determine relevance to the domain. In this study, support that the model and survey instrument both contained the main items in the domain area was found from experts in academia and industry. Initial interviews with practitioners supported the content validity of the proposed research model. Content validity of the scales used in the survey instrument was also supported from both an initial academic and practitioner assessment during a pre-test of the questionnaire. Furthermore, several of the constructs have been drawn from existing academic research in corporate environmental literature and hence this also assisted in achieving content validity.

Cronbach's alpha values were calculated for each of the factors from the proposed model to assess internal consistency reliability and construct validity. As seen in Table 1, the values for all constructs ranged from 0.805 to 0.888 which demonstrates good internal consistency (DeVellis 2003).

\begin{tabular}{|lc|}
\hline Construct & Cronbach's alpha \\
\hline Extent of green IT & 0.819 \\
\hline Competitive pressures & 0.805 \\
\hline Legitimation pressures & 0.888 \\
\hline Social responsibility pressures & 0.855 \\
\hline Organisational factors & 0.880 \\
\hline Technological constraints & 0.862 \\
\hline
\end{tabular}

Table 1. Cronbach's alpha scores for each of the constructs in the model

Independent variables were also tested for multicollinearity and it was found that the tolerance value was above 0.10 illustrating that multicollinearity should not be an issue in these models.

\section{RESULTS}

The results were comprised of 30 responses representing a $52 \%$ response rate. $80 \%$ of respondents identified themselves as non-management professional or technical staff with the remaining $20 \%$ holding a managerial position. 
Most participating respondents were from organisations which were headquartered in Australia $(87 \%)$ and the USA $(10 \%)$. These organisations were either large organisations with more than 500 employees (83\%) or medium-sized with between 100 and 500 employees (17\%). These organisations were from a variety of industries with 'finance and insurance' (43\%) representing a large proportion of responses while 'information' (17\%) and 'manufacturing' (13\%) industries were also represented. Among other industries represented are the 'utilities' and 'educational services' industries. IT within these organisations surveyed were nearly all centralised (47\%) or regionalised $(47 \%)$.

Respondents reported that the initiatives that were most widely known to have been adopted in these organisations include telecommuting (73\% of organisations), collaboration technologies (93\%) and the reduction of paper usage through both the configuration of printers (77\%) and the use of electronic substitutes $(77 \%)$. Policies for electronic waste $(70 \%)$, data centre consolidation $(60 \%)$ and virtualisation $(60 \%)$ were also widely undertaken. Each of the constructs (competitive pressures, legitimation pressures, social responsibility pressures, organisational factors and technological constraints) and their related measures were loaded into the model against the dependent variable extent of green IT. The results of the stepwise regression indicated three measures accounted for most of the variance in the extent of green IT in organisations. These were the capability of the organisation to adapt which reflects organisational factors, the influence of the legal affairs department which reflects legitimation pressures, and the influence of employees which reflects social responsibility pressures. These three measures accounted for $63.4 \%$ of the variance (adjusted R2=0.591) in the extent of green IT in organisations.

Table 2 details each of the models constructed during stepwise regression. The dependent variable in each of these models was the extent of green IT score with the predictor variables for models 1-5 respectively being:

(1) Capability to adapt

(2) Capability to adapt, social responsibility

(3) Capability to adapt, social responsibility, legal affairs department

(4) Capability to adapt, social responsibility, legal affairs department, employees

(5) Capability to adapt, legal affairs department, employees

The addition of the influence of employees during of the stepwise regression resulted in social responsibility no longer being significant in model 4 . This was replaced with the influence of employees in the final regression model. Table 2. Stepwise regression for the extent of green IT in organisations

details the variables of the final model from the stepwise regression.

\begin{tabular}{|llcccccc|} 
Model & R & R Square & $\begin{array}{c}\text { Adjusted } \\
\text { R Square }\end{array}$ & $\begin{array}{c}\text { Std. Error } \\
\text { of the } \\
\text { Estimate }\end{array}$ & $\begin{array}{c}\text { R Square } \\
\text { Change }\end{array}$ & F Change & $\begin{array}{c}\text { Sig. F } \\
\text { Change }\end{array}$ \\
\hline $\mathbf{1}$ & .598 & .358 & .335 & .61194 & .358 & 15.625 & .000 \\
\hline $\mathbf{2}$ & .714 & .510 & .474 & .54432 & .152 & 8.388 & .007 \\
\hline $\mathbf{3}$ & .762 & .581 & .533 & .51290 & .071 & 4.409 & .046 \\
\hline $\mathbf{4}$ & .810 & .656 & .600 & .47444 & .074 & 5.387 & .029 \\
\hline $\mathbf{5}$ & .796 & .634 & .591 & .47972 & -.022 & 1.582 & .220 \\
\hline
\end{tabular}


Table 2. Stepwise regression for the extent of green IT in organisations

\begin{tabular}{|c|c|c|c|c|c|c|c|}
\hline \multirow{2}{*}{$\begin{array}{l}\text { Predictors } \\
\text { (of Model } 5 \\
\text { from Table 2) }\end{array}$} & \multicolumn{2}{|c|}{$\begin{array}{l}\text { Unstandardized } \\
\text { Coefficients }\end{array}$} & \multirow{2}{*}{$\begin{array}{c}\begin{array}{c}\text { Standardized } \\
\text { Coefficients }\end{array} \\
\text { Beta }\end{array}$} & \multirow[t]{2}{*}{$\mathbf{t}$} & \multirow[t]{2}{*}{ Sig. } & \multicolumn{2}{|c|}{ Collinearity Statistics } \\
\hline & B & Std. Error & & & & Tolerance & VIF \\
\hline (Constant) & 1.538 & .291 & & 5.280 & .000 & & \\
\hline $\begin{array}{l}\text { Capability to } \\
\text { adapt }\end{array}$ & .394 & .086 & .667 & 4.589 & .000 & .668 & 1.498 \\
\hline $\begin{array}{l}\text { Legal affairs } \\
\text { department }\end{array}$ & -.343 & .098 & -.532 & -3.502 & .002 & .611 & 1.637 \\
\hline Employees & .360 & .096 & .527 & 3.763 & .001 & .717 & 1.394 \\
\hline
\end{tabular}

Table 3. Stepwise regression independent variable outputs for the extent of green IT in organisations

\section{DISCUSSION}

The capability of the organisation to adapt accounted for $33.5 \%$ of the variance (adjusted) indicating that from the perspective of employees, organisations that were highly capable of change tended to be more developed in the use of green IT. This may be reflective of the fact that green IT is a relatively recent trend and it is likely early adopters and leaders in green IT tend to be organisations that are more proactive and are able to adapt quickly to the changing contexts in which organisations operate. This finding supports the study by James et al. (1999) which found that the capability of organisations to adapt were the foremost internal factor which affected corporate environmental strategy in the financial and utilities industries.

The influence of employees accounted for an additional $8.9 \%$ of the variance (adjusted) in the extent of green IT. As this survey was completed primarily by non-management staff, it is evident that the more influence that employees as a group perceive themselves as having, the more environmental responsive the organisation is perceived to be in their use of green IT. Employees form the internal social responsibility considerations which motivate organisations to pursue initiatives targeted towards morale and social good rather than from compliance, profitability or to appease external parties. The sense of social responsibility having an influence to the extent of green IT supports Hahn and Scheermesser's (2006) study where ecological and social responsibility were the top rated reasons for corporate sustainability activities with more than $90 \%$ of respondents rating each as 'very important' or 'important'. It is also consistent with Molla, Pittayachawan and Corbitt's (2009) study which found that $77 \%$ of respondents considered environmental considerations as one of the main reasons for pursuing green IT.

The influence of an organisation's legal affairs department accounted for an additional $17 \%$ of the variance. "Legal affairs departments are typically the primary channel for pressures from constituents in their organisations' nonmarket environments" (Delmas \& Toffel 2008, p. 1032). It was found however, that these pressures had a negative coefficient which may be reflective of the narrow focus among nonmarket constituents in green IT. People are still currently only primarily concerned with matters of e-waste and hardware recycling (Greenpeace n.d.; Guerin 2009). As legitimation pressures lead organisations to only aim to satisfice external constituents, organisations strongly influenced by their legal affairs department are more likely to be less developed and less inclined to adopt any green IT initiatives other than those which pose a substantial risk to the firm. In the current context, the only risk to organisations is how e-waste is managed. 
Capability of organisation to adapt 0.335 0.667

Employees

0.089

0.527

Legal affairs department

0.170

$-0.532$

Total adjusted $\mathbf{R}^{2}$

0.591

Table 4. Degree to which factors predict extent of green IT

Although cost considerations were rated as the highest influential factor with a mean of 4.17 on a 5point scale, it did not account for any significant variance to the respondent's assessment of their organisation's efforts towards green IT. There was no support for competitive considerations and this may reflect that profitability is a consideration uniform across organisations. It may also indicate that, in the minds of the respondents, the bottom line is always considered and that changes would not be able to adversely affect the cost base. Exploration of this was outside the scope of this study and further work is needed to examine this issue. There was also no support that technological constraints affected the extent to which organisations pursued green IT. This also suggests that the limitations posed by current software, hardware and infrastructure do not influence the extent to which efforts towards green IT are undertaken.

\section{LIMITATIONS AND CONCLUDING REMARKS}

The results indicate that in organisations that have ubiquitous, maximal efforts towards the widespread use of IT to improve environmental performance, these initiatives are more likely to be motivated from a sense of social responsibility from employees within an environment capable of change rather than responding to external legitimation pressures or pursuing competitive advantage. These findings result from exploring the perspective of non-management IT practitioners. Future research on senior managerial perspectives, which may more broadly reflect organisational environmental objectives and more knowledgably comment on organisational practices, may reveal that organisations are subject to different factors.

There are a number of clear limitations in these preliminary findings. Foremost of which is the exploratory nature of the research and small sample size which limits generalisability of these findings. Furthermore, given the recent trend towards green IT, organisational environmental performance may be particularly susceptible to self-report biases where "research participants want to respond in a way that makes them look as good as possible" (Donaldson \& Grant-Vallone 2002, p. 247). For the same reasons, self-selection may also have led to a response bias where respondents more receptive to environmental concerns are more likely to have completed the survey. These limitations need to be carefully considered when interpreting the results and before any generalisations can be made.

Nevertheless the high $\mathrm{R} 2$ reported in this study indicated that the model developed is at least on the right track and provides a good starting point for further research. In this emerging field, these findings have both theoretical and practical implications for organisations and researchers in green IT. This study expands the limited academic work in this area and allows other researchers to better understand the factors driving and enabling environmental sustainability in organisational IS and IT. Therefore, this study may provide researchers with guidance as they conduct future research and develop their own theories. The importance of green IT also cannot be understated to practitioners 
as climate change is one of the greatest challenges facing this generation. Reducing greenhouse gases requires major commitments from organisations and consequently, more research into how organisations can utilise green IT and be motivated towards this trend would be beneficial to individuals, organisations and society. The insights gained exploring this area assists in gaining a clear understanding of the factors that can be used to improve and increase the extent of green IT in organisations. This may then allow organisations to reduce the environmental impact of their IT operations as well as allowing them to utilise IS to improve environment performance in other areas throughout the organisation.

\section{REFERENCES}

Ahmed, N.U. \& Sharma, S.K. (2006), 'Porter's value chain model for assessing the impact of the internet for environmental gains', International Journal of Management and Enterprise Development, vol. 3, no. 3, pp. 278-295.

Banerjee, S.B. (2002), 'Corporate environmentalism: the construct and its measurement', Journal of Business Research, vol. 55, no. 3, pp. 177-191.

Bansal, P. \& Roth, K. (2000), 'Why Companies Go Green: A Model of Ecological Responsiveness', Academy of Management Journal, vol. 43, no. 4, pp. 717-737.

Beurer-Zuellig, B. \& Meckel, M. (2008), 'Smartphones Enabling Mobile Collaboration', 41st Annual Hawaii International Conference on System Sciences.

Bonini, S., Hintz, G. \& Mendonca, L. (2007), 'Assessing the impact of societal issues: A McKinsey Global Survey', The McKinsey Quarterly.

Bonini, S., Hintz, G. \& Mendonca, L. (2008), 'Addressing consumer concerns about climate change', The McKinsey Quarterly, no. 2, pp. 52-61.

Chen, A.J.W., Boudreau, M.C. \& Watson, R.T. (2008), 'Information systems and ecological sustainability', Journal of Systems and Information Technology, vol. 10, no. 3, pp. 186-201.

Cordano, M. (1993), 'Making the natural connection: Justifying investment in environmental innovation', Proceedings of the International Association for Business and Society, pp. 530537.

Delmas, M.A. \& Toffel, M.W. (2008), 'Organizational responses to environmental demands: opening the black box', Strategic Management Journal, vol. 29, pp. 1027-1055.

Deloitte (2008), Green IT: The Fast-track to Enterprise Sustainability, viewed 31 July 2008

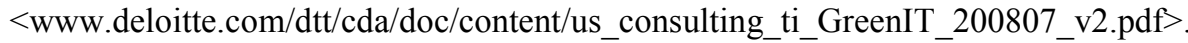

DeVellis, R.F. (2003), Scale Development: Theory and Applications, 2nd edn, Sage Publications, Inc., Thousand Oaks, CA, USA.

Donaldson, S.I. \& Grant-Vallone, E.J. (2002), 'Understanding Self-Report Bias in Organizational Behavior Research', Journal of Business and Psychology, vol. 17, no. 2, pp. 245-260.

Elkington, J. (1998), Cannibals with forks: The triple bottom line of 21 st century business, New Society Publishers, Stony Creek, CT, USA.

Elliot, S. (2007), 'Environmentally Sustainable ICT: A Critical Topic for IS Research?' Pacific Asia Conference on Information Systems (PACIS 2007), Auckland, New Zealand, 3-6 July. 
Elliot, S. \& Binney, D. (2008), 'Environmentally Sustainable ICT: Developing Corporate Capabilities and an industry-relevant IS Research Agenda', Pacific Asia Conference on Information Systems (PACIS 2008), Suzhou, China, 4-6 July.

Enkvist, P.-A., Nauclér, T. \& Oppenheim, J.M. (2008), 'Business strategies for climate change', The McKinsey Quarterly, no. 2, pp. 24-33.

Enkvist, P.-A. \& Vanthournout, H. (2008), 'How companies think about climate change: A McKinsey Global Survey', The McKinsey Quarterly, no. 2, pp. 46-51.

Faulkner, D., Carlisle, Y.M. \& Viney, H.P. (2005), 'Changing corporate attitudes towards environmental policy', Management of Environmental Quality: An International Journal, vol. 16, no. 5, pp. 476-489.

Friedman, T.L. (2007), 'The Power of Green', The New York Times Magazine, viewed 4 August $2008<$ www.nytimes.com/2007/04/15/magazine/15green.t.html>.

Gartner (2007), Gartner Identifies the Top 10 Strategic Technologies for 2008, viewed 2 November $2008<$ www.gartner.com/it/page.jsp?id=530109>.

Gartner (2008), Gartner Identifies the Top 10 Strategic Technologies for 2009, viewed 5 March $2009<$ www.gartner.com/it/page.jsp?id=777212>.

Ghobadian, A., Viney, H., Liu, J. \& James, P. (1998), 'Extending Linear Approaches to Mapping Corporate Evnironmental Behaviour', Business Strategy and the Environment, vol. 7, pp. 13 23.

Ghose, A., Hasan, H. \& Spedding, T. (2008), Carbon-centric Computing: IT Solutions for Climate Change, University of Wollongong Working Group on the Carbon-Centric Computing Initiative, viewed 15 October $2008<$ www.uow.edu.au/ aditya/research/ccci/CCCIinaugural-report.pdf $>$.

Greenpeace n.d., Greener Electronics, viewed 5 June 2009 $<$ www.greenpeace.org/international/campaigns/toxics/electronics>.

Guerin, T. (2009), Behind every device... viewed 3 June 2009 $<$ www.nowwearetalking.com.au/blogs/green-files/behind-every-device>.

Hahn, T. \& Scheermesser, M. (2006), 'Approaches to corporate sustainability among German companies', Corporate Social Responsibility and Environmental Management, vol. 13, no. 3, pp. 121-181.

Hart, S.L. (1995), 'A natural-resource-based view of the firm', Academy of management review, vol. 20, no. 4, pp. 986-1014.

Herat, S. \& Bahadir, M. (2007), 'Sustainable Management of Electronic Waste (e-Waste)', CLEAN - Soil, Air, Water, vol. 35, no. 4, p. 305.

IDC (2008), IDC - Press Release: IT Executives Demonstrate Growing Preference for "Greener" Technology Partners in Latest IDC's Green Poll viewed 2 November 2008 $<$ www.idc.com/getdoc.jsp?containerId=prSG21046108>.

James, P., Ghobadian, A., Viney, H. \& Liu, J. (1999), 'Addressing the divergence between environmental strategy formulation and implementation', Management Decision, vol. 37, no. 4, pp. 338-347.

Katzer, J., Deutch, J., Moniz, E.J., Ansolabehere, S., Beer, J., Ellerman, D., Friedmann, J., Herzog, H., Jacoby, H.D., Joskow, P.L. \& McRae, G. (2007), The Future of Coal, Massachusetts 
Institute of Technology, Cambridge, MA, viewed 1 November 2008

$<$ web.mit.edu/coal/The_Future_of_Coal.pdf $>$.

Molla, A. (2008), 'GITAM: A Model for the Adoption of Green IT', 19th Australasian Conference on Information Systems Christchurch, New Zealand, 3-5 December.

Molla, A., Pittayachawan, S. \& Corbitt, B. (2009), Green IT Diffusion: An International Comparison, Green IT Working Paper Series, viewed 13 May 2009 <greenit.bf.rmit.edu.au/Working_Paper/GITWP1_2009.pdf>.

Organisation for Economic Co-operation and Development (2008), RFID Radio Frequency Identification, Committee for Information, Computer and Communications Policy, Directorate for Science, Technology and Industry, viewed 29 October 2008 $<$ www.oecd.org/dataoecd/19/42/40892347.pdf>.

Porter, M. \& Van der Linde, C. (1995), 'Green and competitive: ending the stalemate', Harvard Business Review, vol. 73, no. 5, pp. 120-134.

PricewaterhouseCoopers \& SAM (2008), The Sustainability Yearbook 2008, viewed 31 October $2008<$ www.sam-group.com/downloads/YB/Yearbook_2008.pdf>.

Russo, M.V.\& Fouts, P.A. (1997), 'A Resource-Based Perspective on Corporate Environmental Performance and Profitability', Academy of Management Journal, vol. 40, no. 3, p. 534.

Sayeed, L. \& Gill, S. (2008), 'An Exploratory Study on Environmental Sustainability and IT Use', Fourteenth Americas Conference on Information Systems (AMCIS 2008), Toronoto, ON, Canada, 14-17 July.

Schein, E.H. (2004), Organizational culture and leadership, 3rd edn, John Wiley and Sons Ltd.

St James Ethics Centre n.d., corporate responsibility index model, viewed 31 October 2008 <www.corporate-responsibility.com.au/about/how_it_works/index_model.asp>.

The Climate Group (2008), SMART 2020: Enabling the low carbon economy in the information age, Global eSustainability Initiative (GeSI).

United Nations Environment Programme (2008), UNEP Year Book 2008, Division of Early Warning and Assessment (DEWA), Nairobi, Kenya, viewed 28 July 2008 $<$ www.unep.org/geo/yearbook/yb2008/report/UNEP_YearBook2008_Full_EN.pdf $>$. 